\title{
Pedobacter sandarakinus sp. nov., isolated from soil
}

\author{
Jung-Hoon Yoon, Mi-Hwa Lee, So-Jung Kang, Soo-Yeon Park \\ and Tae-Kwang Oh \\ Korea Research Institute of Bioscience and Biotechnology (KRIBB), PO Box 115, Yusong, \\ Taejon, Korea
}

Correspondence

Jung-Hoon Yoon

jhyoon@kribb.re.kr

\begin{abstract}
A Gram-negative, non-motile, rod-shaped bacterial strain, designated DS- $27^{\top}$, was isolated from a soil sample, and its taxonomic position was investigated by using a polyphasic approach. The

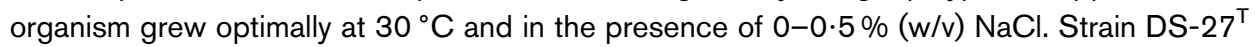
contained MK-7 as the predominant menaquinone and iso- $\mathrm{C}_{15: 0,}, \mathrm{C}_{16: 1} \omega 7 \mathrm{c}$ and/or iso- $\mathrm{C}_{15: 0}$ $2-\mathrm{OH}$ and iso- $\mathrm{C}_{17: 0} 3-\mathrm{OH}$ as the major fatty acids. The DNA G+C content was $39 \cdot 7 \mathrm{~mol} \%$. Phylogenetic analyses based on $16 \mathrm{~S}$ rRNA gene sequences revealed that strain DS- $27^{\top}$ is most closely related to the genus Pedobacter of the family Sphingobacteriaceae. Similarity values between the $16 \mathrm{~S}$ rRNA gene sequences of strain DS- $27^{\top}$ and the type strains of recognized Pedobacter species ranged from $90 \cdot 6$ to $95.5 \%$. Differential phenotypic properties, together with the phylogenetic distinctiveness, were sufficient to categorize strain DS- $27^{\top}$ as representing a species that is separate from recognized Pedobacter species. On the basis of its phenotypic properties and phylogenetic distinctiveness, strain DS-27 ${ }^{\top}\left(=\mathrm{KCTC}_{12559^{\top}}=\mathrm{CIP} 108922^{\top}\right)$ was classified in the genus Pedobacter as a member of a novel species, for which the name Pedobacter sandarakinus sp. nov. is proposed.
\end{abstract}

The genus Pedobacter was proposed by Steyn et al. (1998) with the reclassification of two Sphingobacterium species as Pedobacter heparinus and Pedobacter piscium and the description of two novel species, Pedobacter africanus and Pedobacter saltans. Subsequently, three further species, Pedobacter cryoconitis (Margesin et al., 2003), Pedobacter himalayensis (Shivaji et al., 2005) and Pedobacter caeni (Vanparys et al., 2005), have been described. In this study, we report on the taxonomic characterization of a Pedobacterlike bacterial strain, DS $-27^{\mathrm{T}}$, which was isolated from a soil sample from the island of Dokdo $\left(37^{\circ} 14^{\prime} 12^{\prime \prime} \mathrm{N}, 131^{\circ}\right.$ $52^{\prime} 07^{\prime \prime}$ E), Korea.

Strain DS $-27^{\mathrm{T}}$ was isolated by the standard dilution plating technique on twofold diluted nutrient agar (Difco) at $25{ }^{\circ} \mathrm{C}$. The morphological, physiological and biochemical characteristics of strain DS- $27^{\mathrm{T}}$ were investigated using routine cultivation on trypticase soy agar (TSA; Difco) at $30{ }^{\circ} \mathrm{C}$. Cell morphology was examined by light microscopy (Nikon E600) and transmission electron microscopy. The presence of flagella was determined by transmission electron microscopy using cells from exponentially growing cultures. For transmission electron microscopic observation, cells were negatively stained with $1 \%(\mathrm{w} / \mathrm{v})$ phosphotungstic acid and, following air-drying, the grids were examined

The GenBank/EMBL/DDBJ accession number for the 16S rRNA gene sequence of strain DS- $27^{\top}$ is DQ235228. with a Philips CM-20 transmission electron microscope. Gliding motility was determined as described by Bowman (2000) using quarter-strength trypticase soy broth (TSB; Difco) solidified with $1 \%(\mathrm{w} / \mathrm{v})$ agarose. The Gram reaction was determined using the bioMérieux Gram stain kit according to the manufacturer's instructions. Growth at various temperatures $\left(4-40{ }^{\circ} \mathrm{C}\right)$ was measured on TSA. Growth in the absence of $\mathrm{NaCl}$ and at various $\mathrm{NaCl}$ concentrations $[0 \cdot 5 \%(\mathrm{w} / \mathrm{v})$ and $1 \cdot 0-5 \cdot 0 \%(\mathrm{w} / \mathrm{v})$ at intervals of $1.0 \%$ ] was investigated in TSB prepared according to the formula of the Difco medium except that no $\mathrm{NaCl}$ was used. The $\mathrm{pH}$ range for growth was determined in nutrient broth (Difco) that was adjusted to various $\mathrm{pH}$ values ( $\mathrm{pH} 4 \cdot 5-10.5$ at intervals of $0.5 \mathrm{pH}$ units). The $\mathrm{pH}$ was adjusted prior to sterilization to various levels by the addition of $\mathrm{HCl}$ or $\mathrm{Na}_{2} \mathrm{CO}_{3}$. Growth under anaerobic conditions was determined after incubation in an anaerobic chamber on TSA and on TSA supplemented with nitrate, both of which had been prepared anaerobically using nitrogen. Catalase and oxidase activities and hydrolysis of casein, gelatin, hypoxanthine, starch, Tweens 20, 40, 60 and 80, tyrosine, urea and xanthine were determined as described by Cowan \& Steel (1965). Hydrolysis of aesculin and nitrate reduction were studied as described by Lanyi (1987). The presence of flexirubin pigment was investigated according to the method of Reichenbach (1992). Susceptibility to antibiotics was tested on TSA plates using discs containing the following antibiotics: polymyxin B 
Table 1. Differential phenotypic characteristics of Pedobacter species

Species: 1, P. sandarakinus sp. nov.; 2, P. heparinus; 3, P. africanus; 4, P. piscium; 5, P. saltans; 6, P. cryoconitis; 7, P. himalayensis; 8, P. caeni. Data are from Steyn et al. (1998), Margesin et al. (2003), Shivaji et al. (2005) and Vanparys et al. (2005). +, Positive reaction; -, negative reaction; W, weakly positive reaction; V, variable reaction; ND, not determined. Data in parentheses are for the type strain. All species are positive for catalase, oxidase, hydrolysis of aesculin, activities (not done for P. cryoconitis and P. himalayensis) of esterase lipase (C8), acid phosphatase, alkaline phosphatase, leucine arylamidase and $\beta$-galactosidase, and assimilation of D-glucose, D-mannose, $N$ acetylglucosamine, amygdalin (not done for P. himalayensis), lactose, melibiose (variable for P. saltans), sucrose (variable for P. saltans) and D-trehalose (variable for $P$. saltans). All species are negative for Gram stain, sporulation, urease, production of indole and $\mathrm{H}_{2} \mathrm{~S}$, nitrate reduction, and assimilation of erythritol, methyl $\beta$-D-xyloside, L-sorbose, dulcitol, inositol, D-melezitose, D-lyxose (not done for $P$. himalayensis), D-tagatose (not done for P. himalayensis), D-fucose (not done for P. himalayensis), D-arabitol (not done for P. himalayensis), L-arabitol (not done for P. himalayensis), gluconate (not done for P. himalayensis), adipate (not done for P. himalayensis), caprate (not done for $P$. himalayensis), phenylacetate (not done for $P$. himalayensis), citrate and malate.

\begin{tabular}{|c|c|c|c|c|c|c|c|c|}
\hline Characteristic & 1 & 2 & 3 & 4 & 5 & 6 & 7 & 8 \\
\hline Colony colour & Orange & $\begin{array}{l}\text { Translucent } \\
\text { yellow }\end{array}$ & $\begin{array}{c}\text { Translucent } \\
\text { yellow }\end{array}$ & $\begin{array}{c}\text { Yellow or } \\
\text { creamish white }\end{array}$ & $\begin{array}{l}\text { Light } \\
\text { yellow }\end{array}$ & $\begin{array}{l}\text { Creamish } \\
\text { white }\end{array}$ & $\begin{array}{l}\text { Pale } \\
\text { white }\end{array}$ & $\begin{array}{c}\text { Creamish white } \\
\text { to yellow }\end{array}$ \\
\hline Maximum growth temperature $\left({ }^{\circ} \mathrm{C}\right)$ & 33 & 37 & 37 & $25-30$ & $25-30$ & 25 & 25 & 37 \\
\hline Growth on MacConkey's medium & - & - & - & - & - & - & + & ND \\
\hline Motility & - & Gliding & - & - & Gliding & Gliding & - & - \\
\hline Cell shape & $\begin{array}{l}\text { Rods/long } \\
\text { rods }\end{array}$ & Short rods & ND & Long rods & ND & Long rods & $\begin{array}{l}\text { Long } \\
\text { rods }\end{array}$ & Rods \\
\hline Arginine dihydrolase & - & - & - & - & - & - & + & - \\
\hline Lysine decarboxylase & - & + & + & + & + & - & - & ND \\
\hline Tryptophan deaminase & - & - & - & - & - & - & + & ND \\
\hline \multicolumn{9}{|l|}{ Enzyme activity (API ZYM) } \\
\hline Esterase (C4) & + & $+^{*}$ & - & $+^{*}$ & - & ND & ND & - \\
\hline Lipase $(\mathrm{C} 14)$ & - & $-^{*}$ & - & $\mathrm{V}^{*}$ & - & $\mathrm{ND}$ & ND & - \\
\hline Valine arylamidase & - & $-{ }^{\star}$ & $\mathrm{V}(-)$ & $+^{*}$ & $\mathrm{~V}$ & $\mathrm{ND}$ & ND & - \\
\hline Cystine arylamidase & $\mathrm{W}$ & $+^{*}$ & - & $+^{*}$ & - & ND & ND & - \\
\hline Trypsin & - & $-{ }^{\star}$ & - & $+^{*}$ & - & $\mathrm{ND}$ & ND & - \\
\hline$\alpha$-Chymotrypsin & - & $+^{*}$ & - & $+^{*}$ & - & ND & ND & - \\
\hline$\alpha$-Galactosidase & - & $+^{*}$ & - & $+^{*}$ & - & $\mathrm{ND}$ & ND & - \\
\hline$\beta$-Glucuronidase & - & $-{ }^{*}$ & - & $\mathrm{V}^{*}$ & $\mathrm{~V}$ & ND & ND & - \\
\hline$\alpha$-Glucosidase & + & + & + & + & + & $\mathrm{ND}$ & $\mathrm{ND}$ & - \\
\hline$\beta$-Glucosidase & + & $+^{*}$ & $\mathrm{~V}(-)$ & $+^{*}$ & + & + & + & - \\
\hline$N$-Acetyl- $\beta$-glucosaminidase & + & + & + & + & + & $\mathrm{ND}$ & ND & - \\
\hline$\alpha$-Mannosidase & - & $+^{*}$ & $\mathrm{~V}(\mathrm{w})$ & $+^{*}$ & - & ND & ND & - \\
\hline$\alpha$-Fucosidase & - & $-{ }^{\star}$ & - & $-{ }^{\star}$ & - & $\mathrm{ND}$ & ND & - \\
\hline \multicolumn{9}{|l|}{ Assimilation of: } \\
\hline Glycerol & - & - & - & - & + & - & + & - \\
\hline D-Arabinose & - & - & $\mathrm{V}(-)$ & - & $\mathrm{V}$ & - & + & - \\
\hline L-Arabinose & - & + & $\mathrm{v}(+)$ & + & + & + & + & + \\
\hline Ribose & - & - & $\mathrm{V}(-)$ & - & - & - & + & - \\
\hline D-Xylose & - & + & $\mathrm{V}(+)$ & + & + & + & + & - \\
\hline L-Xylose & - & - & - & - & - & - & + & + \\
\hline Adonitol & - & + & - & - & + & - & + & - \\
\hline D-Galactose & + & + & + & $\mathrm{V}$ & + & + & + & - \\
\hline D-Fructose & - & + & $\mathrm{V}(-)$ & + & $\mathrm{V}$ & + & + & - \\
\hline L-Rhamnose & - & + & + & V & + & - & + & - \\
\hline Mannitol & - & + & - & - & - & - & + & - \\
\hline D-Sorbitol & - & + & - & - & - & - & + & - \\
\hline Methyl $\alpha$-D-mannoside & $\mathrm{W}$ & + & + & - & - & - & + & + \\
\hline Methyl $\alpha$-D-glucoside & $\mathrm{W}$ & + & + & + & $\mathrm{V}$ & $\mathrm{W}$ & + & + \\
\hline Arbutin & - & $\mathrm{V}(-)$ & $\mathrm{V}(-)$ & + & + & + & + & + \\
\hline Salicin & + & + & $\mathrm{v}(+)$ & + & + & + & + & + \\
\hline D-Cellobiose & + & + & + & + & - & + & + & + \\
\hline
\end{tabular}


Table 1. cont.

\begin{tabular}{|c|c|c|c|c|c|c|c|c|}
\hline Characteristic & 1 & 2 & 3 & 4 & 5 & 6 & 7 & 8 \\
\hline Maltose & + & + & $\mathrm{v}(+)$ & + & + & + & + & + \\
\hline Inulin & - & - & - & - & - & $\mathrm{W}$ & + & - \\
\hline Starch & + & - & $\mathrm{V}(-)$ & + & - & + & + & + \\
\hline Glycogen & + & - & - & - & - & + & - & - \\
\hline D-Turanose & - & + & + & + & V & + & ND & - \\
\hline L-Fucose & - & + & $\mathrm{V}(-)$ & - & - & - & + & - \\
\hline 2-Ketogluconate & - & - & - & - & - & + & $\mathrm{ND}$ & - \\
\hline 5-Ketogluconate & + & - & - & - & - & - & $\mathrm{ND}$ & - \\
\hline \multicolumn{9}{|l|}{ Susceptibility to antibiotics } \\
\hline Tetracycline & + & + & - & $\mathrm{ND}$ & + & - & - & + \\
\hline DNA G $+C$ content $(\mathrm{mol} \%)$ & $39 \cdot 7$ & $42 \cdot 3-43 \cdot 0$ & $43 \cdot 7-44 \cdot 2$ & $40 \cdot 4-41 \cdot 0$ & $36 \cdot 9-37 \cdot 1$ & $43 \cdot 4$ & $41 \cdot 0$ & $42 \cdot 7$ \\
\hline
\end{tabular}

${ }^{\star}$ Data from Takeuchi \& Yokota (1992).

(100 U), streptomycin (50 $\mathrm{g}$ ), penicillin G (20 U), chloramphenicol $(100 \mu \mathrm{g})$, ampicillin $(10 \mu \mathrm{g})$, cephalothin $(30 \mu \mathrm{g})$, gentamicin $(30 \mu \mathrm{g})$, novobiocin $(5 \mu \mathrm{g})$, tetracycline $(30 \mu \mathrm{g})$, kanamycin $(30 \mu \mathrm{g})$, lincomycin $(15 \mu \mathrm{g})$, oleandomycin $(15 \mu \mathrm{g})$, neomycin $(30 \mu \mathrm{g})$ and carbenicillin $(100 \mu \mathrm{g})$. Assimilation of various substrates, enzyme activity and other physiological and biochemical properties were tested by using the API 20E, API 50CHB and API ZYM systems (bioMérieux).

Cell biomass for DNA extraction and for isoprenoid quinone analysis was obtained from cultivation in TSB at $30{ }^{\circ} \mathrm{C}$. Chromosomal DNA was isolated and purified according to the method described by Yoon et al. (1996), with the exception that RNase T1 was used in combination with RNase A to minimize contamination with RNA. The 16S rRNA gene was amplified by PCR using two universal primers as described previously (Yoon et al., 1998). Sequencing of the amplified 16S rRNA gene and phylogenetic analysis were performed as described by Yoon et al. (2003). Isoprenoid quinones were extracted according to the method of Komagata \& Suzuki (1987) and analysed using reversed-phase HPLC and a YMC ODS-A $(250 \times 4.6 \mathrm{~mm})$ column. For fatty acid methyl ester analysis, cell mass of strain DS- $27^{\mathrm{T}}$ was harvested from TSA plates after incubation for 5 days at $30{ }^{\circ} \mathrm{C}$. The fatty acid methyl esters were extracted and prepared according to the standard protocol of the MIDI/Hewlett Packard Microbial Identification System (Sasser, 1990). The DNA G + C content was determined by the method of Tamaoka \& Komagata (1984) with a modification that DNA was hydrolysed and the resultant nucleotides were analysed by reversed-phase HPLC.
Morphological, cultural, physiological and biochemical characteristics of strain DS- $27^{\mathrm{T}}$ are given in the species description (see later) or are shown in Table 1. The almost complete 16S rRNA gene sequence of strain DS- $27^{\mathrm{T}}$, comprising $1475 \mathrm{nt}$ (approximately $96 \%$ of the Escherichia coli $16 \mathrm{~S}$ rRNA gene sequence), was determined in this study. The $16 \mathrm{~S}$ rRNA gene sequence analyses showed that strain DS $-27^{\mathrm{T}}$ was phylogenetically most closely affiliated to the genus Pedobacter of the family Sphingobacteriaceae (Fig. 1). In the neighbour-joining tree based on $16 \mathrm{~S}$ rRNA gene sequences, strain DS $-27^{\mathrm{T}}$ joined the cluster comprising Pedobacter species, except $P$. saltans, with a bootstrap resampling value of $99.8 \%$ (Fig. 1). P. saltans exhibited low 16S rRNA gene sequence similarity values to other Pedobacter species $(89 \cdot 9-91 \cdot 4 \%)$ as well as to strain DS-27 ${ }^{\mathrm{T}}$, and joined the cluster comprising Sphingobacterium species with a high bootstrap resampling value (Fig. 1). Accordingly, $P$. saltans may have to be reclassified as a member of the genus Sphingobacterium or within a new genus. The same tree topology was found in the trees generated with the maximum-likelihood and maximum-parsimony algorithms (Fig. 1). Strain DS $-27^{\mathrm{T}}$ exhibited $16 \mathrm{~S}$ rRNA gene sequence similarity values of $90.6 \%$ to $P$. saltans DSM $12145^{\mathrm{T}}$, 93.2-95.5\% to the type strains of the other Pedobacter species and $<90.8 \%$ to the other species used in the phylogenetic analysis.

Strain DS-27 ${ }^{\mathrm{T}}$ contained menaquinone-7 (MK-7), at a peak area ratio of approximately $92 \%$, as the predominant isoprenoid quinone. The fatty acid profile of strain DS$27^{\mathrm{T}}$ included $(>1 \cdot 0 \%$ of the total fatty acids): branched fatty acids iso- $\mathrm{C}_{15: 0}(35 \cdot 8 \%)$, iso- $\mathrm{C}_{17: 1} \omega 9 c(3 \cdot 8 \%)$ and 


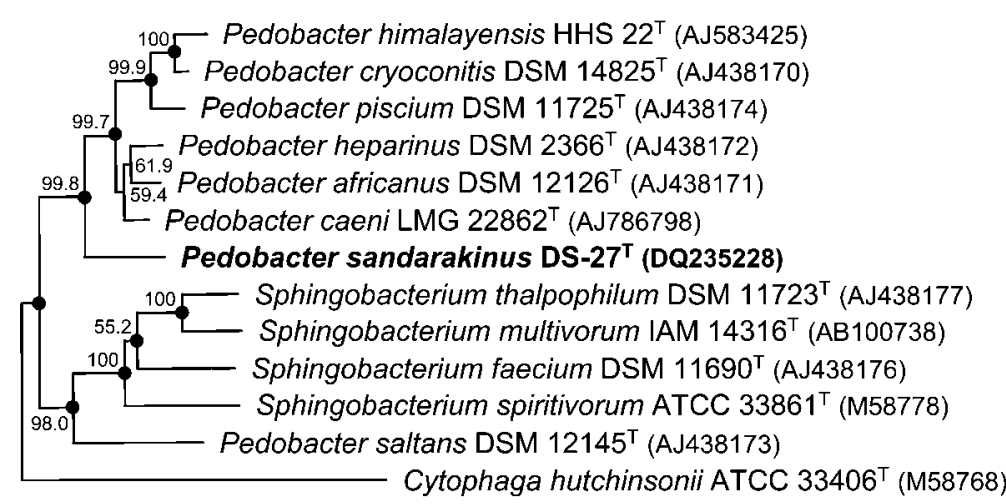

$\underline{0.02}$
Fig. 1. Neighbour-joining phylogenetic tree based on 16S rRNA gene sequences showing the positions of strain DS- $27^{\top}$ and some other related taxa. Bootstrap values of $>50 \%$ (1000 replications) are shown at each node. Cytophaga hutchinsonii ATCC $33406^{\top}$ was used as outgroup. Dots indicate that the corresponding nodes were also recovered in the trees generated with the maximumlikelihood and maximum-parsimony algorithms. Bar, 0.02 substitutions per nucleotide position. iso- $\mathrm{C}_{17: 0}(1 \cdot 8 \%)$; summed feature 3 , comprising $\mathrm{C}_{16: 1} \omega 7 c$ and/or iso- $\mathrm{C}_{15: 0} 2-\mathrm{OH}(21 \cdot 7 \%)$; hydroxy fatty acids iso$\mathrm{C}_{17: 0} 3-\mathrm{OH}(17 \cdot 7 \%)$, iso- $\mathrm{C}_{15: 0} 3-\mathrm{OH}(3 \cdot 0 \%)$ and $\mathrm{C}_{15: 0}$ $2-\mathrm{OH}(1 \cdot 2 \%)$; straight-chain fatty acid $\mathrm{C}_{15: 0}(4 \cdot 2 \%)$; and unsaturated fatty acids $\mathrm{C}_{15: 1} \omega 6 c(1 \cdot 6 \%)$ and $\mathrm{C}_{17: 1} \omega 8 c$ $(1 \cdot 1 \%)$. This fatty acid profile was similar to those of Pedobacter species analysed previously, although there were differences in the proportions of some fatty acids, perhaps because of differences in cultivation conditions (Steyn et al., 1998; Shivaji et al., 2005; Vanparys et al., 2005). The DNA $\mathrm{G}+\mathrm{C}$ content of strain DS- $27^{\mathrm{T}}$ was $39 \cdot 7 \mathrm{~mol} \%$. There were no distinct phenotypic, particularly chemotaxonomic, properties to differentiate strain DS- $27^{\mathrm{T}}$ from the genus Pedobacter (Steyn et al., 1998; Margesin et al., 2003; Shivaji et al., 2005; Vanparys et al., 2005). Accordingly, it was concluded that strain DS $-27^{\mathrm{T}}$ is more closely affiliated to the genus Pedobacter than it is to the genus Sphingobacterium, based on phylogenetic and chemotaxonomic relatedness, the absence of urease activity and the inability to assimilate D-melezitose (Steyn et al., 1998; Shivaji et al., 2005; Vanparys et al., 2005). Strain DS- $27^{\mathrm{T}}$ was distinguishable from recognized Pedobacter species based on several phenotypic characteristics as listed in Table 1 . The $16 \mathrm{~S}$ rRNA gene sequence similarity values were low enough to allocate strain $\mathrm{DS}-27^{\mathrm{T}}$ to a species that is separate from the recognized Pedobacter species (Stackebrandt \& Goebel, 1994). Therefore, on the basis of the data presented, strain DS- $27^{\mathrm{T}}$ should be placed in the genus Pedobacter as a member of a novel species, for which the name Pedobacter sandarakinus sp. nov. is proposed.

\section{Description of Pedobacter sandarakinus sp. nov.}

Pedobacter sandarakinus [san.da.ra.ki'nus. N.L. masc. adj. sandarakinus (from Gr. adj. sandarakinos) orangecoloured].

Cells are Gram-negative, non-spore-forming, nonflagellated rods $(0 \cdot 3-0 \cdot 5 \times 0 \cdot 7-4 \cdot 0 \mu \mathrm{m})$; occasionally cells $>50 \mu \mathrm{m}$ in length may occur. Colonies on TSA are circular, convex, smooth, glistening, orange-coloured and $1.5-2.5 \mathrm{~mm}$ in diameter after incubation for 5 days at $30{ }^{\circ} \mathrm{C}$. Optimal growth occurs at $30^{\circ} \mathrm{C}$; growth occurs at
4 and $33{ }^{\circ} \mathrm{C}$, but not at $34^{\circ} \mathrm{C}$. Optimal pH for growth is $7 \cdot 0-7 \cdot 5$; growth occurs at $\mathrm{pH} 5 \cdot 5$, but not at $\mathrm{pH} 5 \cdot 0$. Optimal growth occurs in the presence of $0-0.5 \%(\mathrm{w} / \mathrm{v})$ $\mathrm{NaCl}$; growth does not occur in the presence of $>3 \%(\mathrm{w} / \mathrm{v})$ $\mathrm{NaCl}$. Growth does not occur under anaerobic conditions on TSA or on TSA supplemented with nitrate. Tweens 20, 40, 60 and 80 are hydrolysed, but casein, gelatin, starch, hypoxanthine, xanthine and L-tyrosine are not. Flexirubintype pigments are absent. In assays with the API ZYM system, naphthol-AS-BI-phosphohydrolase is present. Susceptible to novobiocin, lincomycin and oleandomycin, but not to polymyxin B, streptomycin, cephalothin, gentamicin, carbenicillin or neomycin. The predominant menaquinone is MK-7. The major fatty acids ( $>10 \%$ of total fatty acids) are iso- $\mathrm{C}_{15: 0}, \mathrm{C}_{16: 1} \omega 7 c$ and/or iso- $\mathrm{C}_{15: 0}$ 2-OH and iso- $\mathrm{C}_{17: 0}$ 3-OH. The DNA $\mathrm{G}+\mathrm{C}$ content is $39.7 \mathrm{~mol} \%$ (HPLC). Other phenotypic properties are shown in Table 1.

The type strain, DS $-27^{\mathrm{T}}\left(=\mathrm{KCTC} 12559^{\mathrm{T}}=\mathrm{CIP} 108922^{\mathrm{T}}\right)$, was isolated from soil.

\section{Acknowledgements}

This work was supported by the 21C Frontier program of Microbial Genomics and Applications (grant MG05-0401-2-0) from the Ministry of Science and Technology (MOST) of the Republic of Korea.

\section{References}

Bowman, J. P. (2000). Description of Cellulophaga algicola sp. nov., isolated from the surfaces of Antarctic algae, and reclassification of Cytophaga uliginosa (ZoBell and Upham 1944) Reichenbach 1989 as Cellulophaga uliginosa comb. nov. Int J Syst Evol Microbiol 50, 1861-1868.

Cowan, S. T. \& Steel, K. J. (1965). Manual for the Identification of Medical Bacteria. London: Cambridge University Press.

Komagata, K. \& Suzuki, K.-I. (1987). Lipid and cell wall analysis in bacterial systematics. Methods Microbiol 19, 161-207.

Lanyi, B. (1987). Classical and rapid identification methods for medically important bacteria. Methods Microbiol 19, 1-67. 
Margesin, R., Spröer, C., Schumann, P. \& Schinner, F. (2003). Pedobacter cryoconitis sp. nov., a facultative psychrophile from alpine glacier cryoconite. Int J Syst Evol Microbiol 53, 1291-1296.

Reichenbach, H. (1992). The order Cytophagales. In The Prokaryotes. A Handbook on the Biology of Bacteria: Ecophysiology, Isolation, Identification, Applications, 2nd edn, pp. 3631-3675. Edited by A. Balows, H. G. Trüper, M. Dworkin, W. Harder \& K. H. Schleifer. New York: Springer.

Sasser, M. (1990). Identification of Bacteria by Gas Chromatography of Cellular Fatty Acids. Newark, DE: MIDI.

Shivaji, S., Chaturvedi, P., Reddy, G. S. N. \& Suresh, K. (2005). Pedobacter himalayensis sp. nov., from the Hamta glacier located in the Himalayan mountain ranges of India. Int J Syst Evol Microbiol 55, 1083-1088.

Stackebrandt, E. \& Goebel, B. M. (1994). Taxonomic note: a place for DNA-DNA reassociation and $16 \mathrm{~S}$ rRNA sequence analysis in the present species definition in bacteriology. Int J Syst Bacteriol 44, 846-849.

Steyn, P. L., Segers, P., Vancanneyt, M., Sandra, P., Kersters, K. \& Joubert, J. J. (1998). Classification of heparinolytic bacteria into a new genus, Pedobacter, comprising four species: Pedobacter heparinus comb. nov., Pedobacter piscium comb. nov., Pedobacter africanus sp. nov. and Pedobacter saltans sp. nov. Proposal of the family Sphingobacteriaceae fam. nov. Int J Syst Bacteriol 48, 165-177.
Takeuchi, M. \& Yokota, A. (1992). Proposals of Sphingobacterium faecium sp. nov., Sphingobacterium piscium sp. nov., Sphingobacterium heparinum comb. nov., Sphingobacterium thalpophilum comb. nov., and two genospecies of the genus Sphingobacterium, and synonymy of Flavobacterium yabuuchiae and Sphingobacterium spiritivorum. $J$ Gen Appl Microbiol 38, 465-482.

Tamaoka, J. \& Komagata, K. (1984). Determination of DNA base composition by reverse-phase high-performance liquid chromatography. FEMS Microbiol Lett 25, 125-128.

Vanparys, B., Heylen, K., Lebbe, L. \& De Vos, P. (2005). Pedobacter caeni sp. nov., a novel species isolated from a nitrifying inoculum. Int J Syst Evol Microbiol 55, 1315-1318.

Yoon, J.-H., Kim, H., Kim, S.-B., Kim, H.-J., Kim, W. Y., Lee, S. T., Goodfellow, M. \& Park, Y.-H. (1996). Identification of Saccharomonospora strains by the use of genomic DNA fragments and rRNA gene probes. Int J Syst Bacteriol 46, 502-505.

Yoon, J.-H., Lee, S. T. \& Park, Y.-H. (1998). Inter- and intraspecific phylogenetic analysis of the genus Nocardioides and related taxa based on 16S rRNA gene sequences. Int J Syst Bacteriol 48, 187-194.

Yoon, J.-H., Kim, I.-G., Shin, D.-Y., Kang, K. H. \& Park, Y.-H. (2003). Microbulbifer salipaludis sp. nov., a moderate halophile isolated from a Korean salt marsh. Int J Syst Evol Microbiol 53, 53-57. 